\title{
Literary Clinical Review: Effects of Acupuncture on Fibromyalgia
}

\author{
Eva Coelho da Silva, Dilene Francisca Pereira de Sousa, Daniela Santos do Nascimento, \\ Amanda Aguiar Barros, Agrinazio Geraldo Nascimento Neto, Pietra Diovanna da Silva Souza, \\ Randra Karoline Rodrigues Inacio, Raylany Negreiros de Sousa, Larissa dos Santos Nascimento \\ Oliveira, Morgane Ribeiro de Aquino Macedo, Magno De Oliveira, Warly Neves de Araujo
}

\begin{abstract}
Fibromyalgia (FM) is a chronic and rheumatological disease that causes generalized pain by the body, being able to dispose of the person from any activity, even the simple act of sleeping, because of the pains become unbearable. Traditional Chinese Medicine (TCM), is one of the options for an indication of acupuncture used as an alternative for the treatment of fibromyalgia and the possibility of offering patient improvement in the quality of life. This research aims to corroborate through a bibliographic review of recent studies and evidence that designates the effectiveness of acupuncture for patients with fibromyalgia. The methods used for this review work were based on the methodology of the experimental factorial planning article: A brief review, published in the journal International Journal of Advanced Engineering Research and Science (IJAERS). Due to the studies done, it was explicit that the treatment for fibromyalgia using acupuncture has great benefits because patients suffering from pain and use this technique as a treatment option make less use of medication, have less frequent crises and, as a result, more quality of life. It is concluded that acupuncture has physiological bases that prove its effectiveness in the treatment of fibromyalgia symptoms, thus becoming another relevant treatment option for patients with FM to increase their quality of life.
\end{abstract}

Index Terms-Ache, Acupuncture, Fibromyalgia, Treatment.

Eva Coelho da Silva, Graduate student in Physiotherapy, University of Gurupi Unirg, Avenue. Rio de Janeiro. N 1585 - Sector. Central., Gurupi, 77403-090, Tocantins, Brazil

Dilene Francisca Pereira de Sousa, Graduate student in Physiotherapy, University of Gurupi Unirg, Gurupi, Tocantins, Brazil

Daniela Santos do Nascimento, Graduate student in Physiotherapy,

University of Gurupi Unirg, Gurupi, Tocantins, Brazil

Amanda Aguiar Barros, Graduate student in Physiotherapy, University of Gurupi Unirg, Tocantins, Brazil

Agrinazio Geraldo Nascimento Neto, Graduate student in Physiotherapy, University of Gurupi Unirg, Gurupi, Tocantins, Brazil

Pietra Diovanna da Silva Souza, Physiotherapy Student, University of Gurupi Unirg, Gurupi, Tocantins, Brazil

Randra karoline Rodrigues Inacio, Physiotherapy Student - University of Gurupi Unirg,, Gurupi, Tocantins, Brazil

Raylany Negreiros de Sousa, Physiotherapy Student, University of Gurupi Unirg. Gurupi, Tocantins, Brazil

Larissa dos santos nascimento Oliveira, Physiotherapy Student, University of Gurupi Unirg- Gurupi,, Tocantins, Brazil

Morgane Ribeiro de Aquino Macedo, Physiotherapy Graduate, University of Gurupi Unirg,. Gurupi, Tocantins, Brazil

Magno De Oliveira, Master in Biotechnology, Physiotherapy Department, University of Gurupi Unirg, Avenue. Rio de Janeiro. N $\circ 1585$ - Sector. Central., Gurupi, 77403-090, Tocantins, Brazil

Warly Neves de Araujo, Graduated in Physiotherapy, Physiotherapy Department, University of Gurupi Unirg,, Gurupi, Tocantins, Brazil

\section{INTRODUCTION}

Fibromyalgia (FM) is a non-inflammatory syndrome that manifests itself in the musculoskeletal system through generalized chronic pain, often associating with other symptoms, such as chronic tiredness (fatigue), insomnia or nonrestorative sleep, and mood disorders such as anxiety and depression, difficulty concentrating and memory changes, recurrent headache, palpitations, paresthesias, and diarrhea. Fibromyalgia is a chronic and rheumatological disease, being able to dispose of the person from any activity, even the simple act of sleeping because the pains become unbearable $[1,2]$.

The first cases of fibromyalgia, according to studies from the mid-1970s, were evidenced where diagnostic criteria were reported through pain for more than three months throughout the body, and presence of hypagic points designated "points although there are painful signs in the musculature, there is no evidence of deformities in the organs and joints [3].

\section{Clinical manifestations}

The main symptoms that characterize fibromyalgia are generalized pains and recurrences so that sometimes it is not even possible to list where it hurts, touch sensitivity, irritable bowel syndrome, restless legs sensation, abdominal pain, burning, tingling, difficulties in urinating, headache, tiredness, non-restorative sleep, mood variation, insomnia, lack of memory and concentration, morning muscle contractures, persistent fatigue throughout the day, pains that worsen with physical exertion and depressive conditions and anxious [4].

Traditional Chinese Medicine (MTC), is one of the options for an indication of acupuncture used as an alternative for the treatment of fibromyalgia and the possibility of offering the patient improvement in the quality of life [5,6]. According to Dirceu de Lavor Sales, president of the Brazilian Medical College of Acupuncture, in an interview for the site www.bonde.com.br, the practice has shown great efficacy to alleviate the pains and limitations of patients suffering from fibromyalgia, chronic generalized pain throughout the body, which affects $2 \%$ of the population, eight of which are women for each man [7].

Any structures of the organism are originally in harmony by the performance of energies Yin (Negative) e Yang 


\section{Literary Clinical Review: Effects of Acupuncture on Fibromyalgia}

(Positive), according to acupuncture theory. In this way, if the energies Yin and Yang continue in sublime harmony, the organism will most likely be healthy. On the other hand, an imbalance will generate the disease. Due to its technique and methodologies, acupuncture tends to stimulate reflex points that have the specificity to regain balance, thus achieving therapeutic benefits [8].

\section{ACUPUNCTURE MECHANISM OF ACTION}

Acupuncture applications help patients with fibromyalgia in pain relief (with an important decrease in painful sensation), improved sleep, mood, and fatigue (through the action of acupuncture of release of endogenous opioids and neurotransmitters such as serotonin, endorphin). Stimulation of these needle points can promote pain control and regain balance, reaching the expected results. Thus, many patients with chronic pain resort to treatment by this technique $[9,10$, 11]. This research aims to corroborate through a bibliographic review of recent studies and evidence that designates the effectiveness of acupuncture for patients with fibromyalgia.

\section{MATERIALS AND METHODS}

The methods used for this work were based on the methodology of the article Experimental Planning Factorial: A brief Review de (OLIVEIRA et al., 2018) [12], published in the journal International Journal of Advanced Engineering Research and Science (IJAERS).

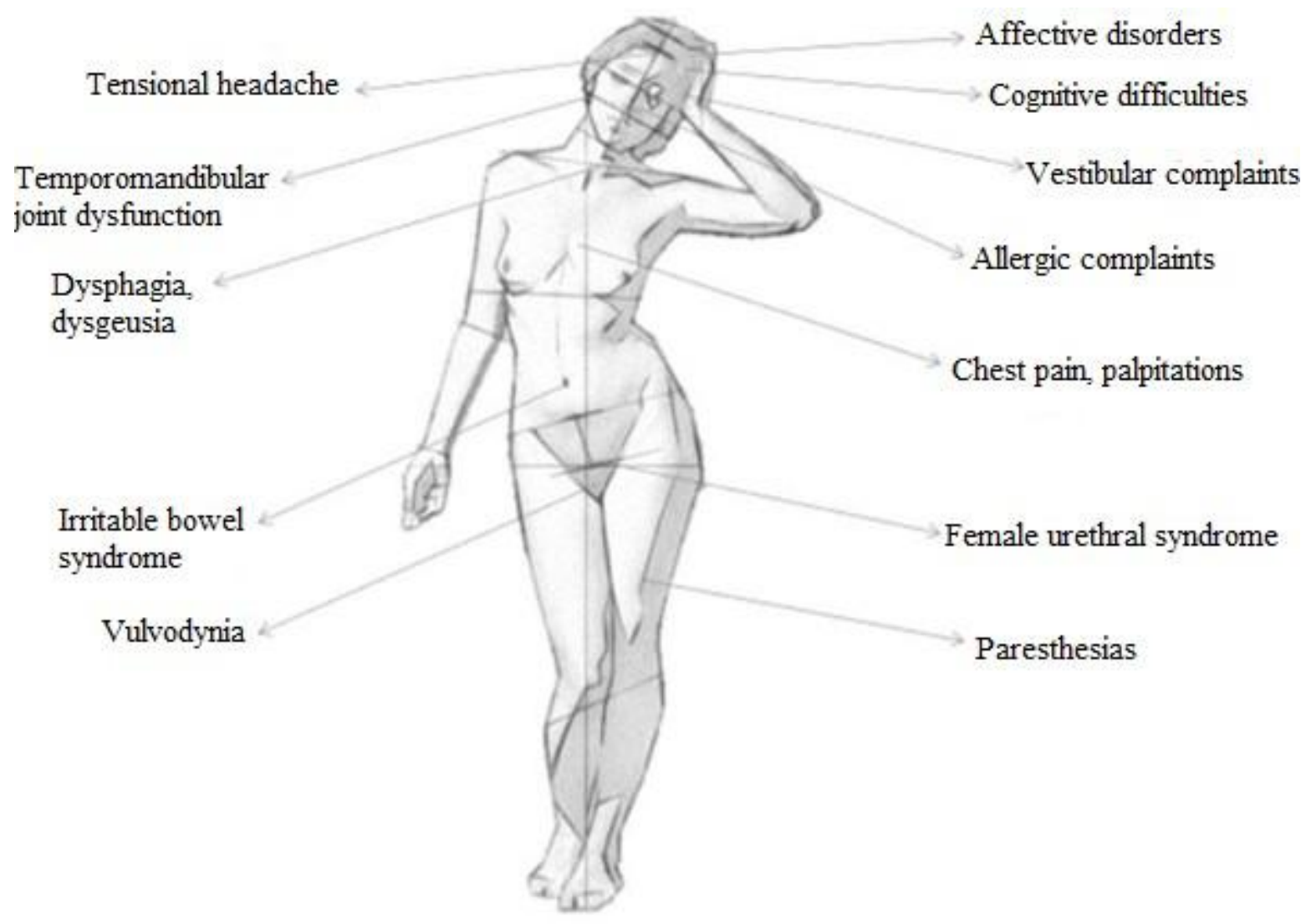

Fig. 1.Symptomatic areas of fibromyalgia (AZEVEDO, 2018).

To identify the articles on the subject, a search was carried out in the databases PubMed, Google Scholar, Virtual Health Library (VHL). Acupuncture is a needle bite therapy from Traditional Chinese Medicine (TCM). Numerous studies indicate better results in pain relief and recovery time when acupuncture is applied in the treatment of fibromyalgia patients. The search strategy on the subject consisted of the use of English keywords: 1. Ache, 2. Acupuncture, 3. Fibromyalgia e 4. Treatment. After consulting the databases and applying the search strategy, repeated studies were identified between the different searches. The inclusion criteria of the articles were: original and research articles that conceptualize the research on the effectiveness of acupuncture in patients with fibromyalgia, in several types of research fields, covering research completed in the language Portuguese, English, and Spanish.

The excluded articles were grouped in the order: repeated, irrelevant, review, other publishing formats (notice, short communications, perspectives, letters), and other languages. In addition, manual searches were made in bibliographic references of review articles found with predetermined keywords. 


\section{RESULTS}

After removing repeated articles between the different searches, the exclusion criteria were applied, as shown in Figure 2. Of the remaining 33 articles, 16 original research articles were retrieved, related to the benefits of acupuncture for fibromyalgia patients. Articles were not recovered through manual search.
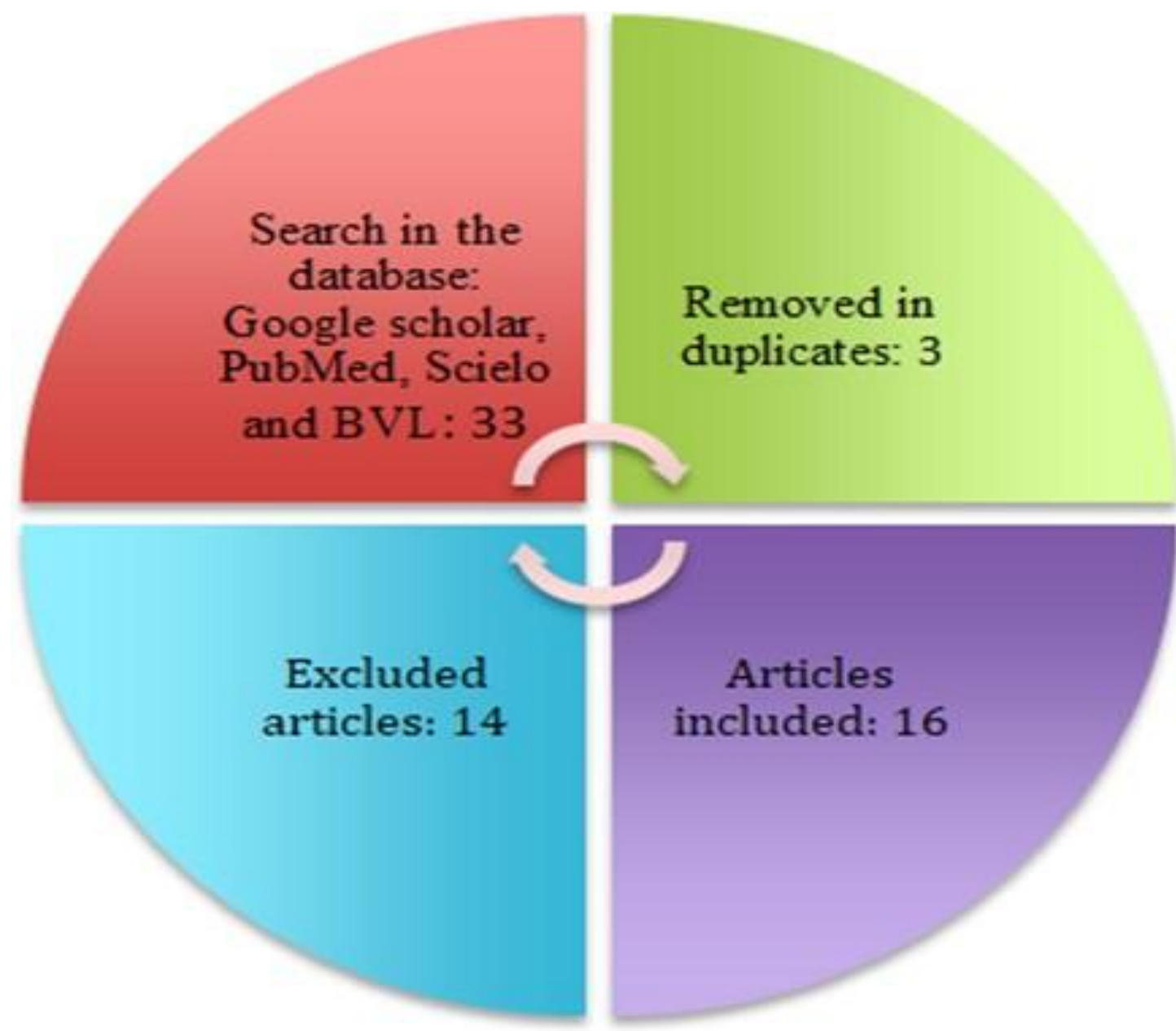

Fig. 2. Flowchart of identification and selection of articles. (Prepared by the authors, 2020).

The articles of use in this review, after exclusion criteria, were related and correlated homologously with fibromyalgia, a rheumatological pathology with higher incidences in women, considering their treatment with acupuncture, therapy of the Traditional Chinese Medicine for Symptom Relief.

\section{RESULTS AND DISCUSSION}

Due to the studies done, it was explicit that the treatment for fibromyalgia using acupuncture has great benefits because patients suffering from pain and use this technique as a treatment option make less use of medication, have crises and, as a result, more quality of life. Therefore, undoubtedly, acupuncture has high efficiency in energy rebalancing and, in the reduction of chronic fibromyalgia pain in the human body. Although this pathology does not have a cure, this method contributes to pain relief, improvement in sleep quality and patient life comfort so that it can live with the disease.

Table 1. Shows a systematic review. Articles whose characteristics were related to acupuncture effects as a form of absolute or adjuvant treatment for people with fibromyalgia were selected.

\begin{tabular}{|c|c|c|c|c|}
\hline Author/Year & Goal & Methodology & Results & Conclusion \\
\hline [1] (Beck \& Oliveira, & $\begin{array}{c}\text { Thus, this } \\
\text { study aims to } \\
\text { identify in the } \\
\text { literature }\end{array}$ & $\begin{array}{c}\text { The present } \\
\text { study consisted of a } \\
\text { systematic review } \\
\text { related to the use of }\end{array}$ & $\begin{array}{c}\text { Thus, it was observed } \\
\text { in the literature that } \\
\text { acupuncture has benefit } \\
\text { in the pain treatment of }\end{array}$ & $\begin{array}{c}\text { Acupuncture, } \\
\text { indicated in the national } \\
\text { and international }\end{array}$ \\
\hline
\end{tabular}


Literary Clinical Review: Effects of Acupuncture on Fibromyalgia

\begin{tabular}{|c|c|c|c|c|}
\hline & $\begin{array}{l}\text { studies related } \\
\text { to the use of } \\
\text { acupuncture in } \\
\text { the pain } \\
\text { treatment of } \\
\text { fibromyalgia. }\end{array}$ & $\begin{array}{l}\text { acupuncture in the } \\
\text { pain treatment of } \\
\text { fibromyalgia. }\end{array}$ & $\begin{array}{l}\text { fibromyalgia, associated } \\
\text { or not with another type } \\
\text { of treatment, and it is } \\
\text { also evident that } \\
\text { regardless of the number } \\
\text { of sessions used, the } \\
\text { effect is positive not only } \\
\text { in the treatment of pain } \\
\text { but in several other } \\
\text { symptoms, improving } \\
\text { the general condition of } \\
\text { the patient. }\end{array}$ & $\begin{array}{l}\text { literature as an } \\
\text { alternative technique for } \\
\text { the pain treatment of } \\
\text { Fibromyalgia and } \\
\text { associated symptoms } \\
\text { showing effective results } \\
\text { in its symptomatology. }\end{array}$ \\
\hline $\begin{array}{l}\text { [13] (TAKIGUCHI et al., } \\
\text { 2008) }\end{array}$ & $\begin{array}{c}\text { This random } \\
\text { clinical trial } \\
\text { aimed to verify } \\
\text { the efficacy of } \\
\text { acupuncture in } \\
\text { improving pain, } \\
\text { sleep equality } \\
\text { of life of } \\
\text { fibromyalgia } \\
\text { patients. }\end{array}$ & $\begin{array}{c}\text { Among } 20 \\
\text { women with a mean } \\
\text { age of } 44 \text { years, } \\
\text { diagnosed with } \\
\text { fibromyalgia } \\
\text { according to criteria } \\
\text { do Colégio } \\
\text { American } \\
\text { Rheumatology, the } \\
\text { study 12, randomly } \\
\text { distributed in two } \\
\text { groups: A (GA, } \\
\text { n=5), which } \\
\text { received } \\
\text { acupuncture } \\
\text { according to } \\
\text { traditional Chinese } \\
\text { medicine; and B } \\
\text { (GB, } \mathrm{n}=7 \text { ), which } \\
\text { had the insertion of } \\
\text { needles in the base } \\
\text { points of occipital, } \\
\text { trapezoid, } \\
\text { supraspinous and } \\
\text { lateral epicondyle. }\end{array}$ & $\begin{array}{l}\text { In GA, there was a } \\
\text { statistically significant } \\
\text { improvement in sleep; } \\
\text { and in GB, pain, pain } \\
\text { threshold in tender } \\
\text { points, sleep and QIF } \\
\text { items pain, morning } \\
\text { tiredness, anxiety and } \\
\text { depression }(\mathrm{p}<0.05) \text {. }\end{array}$ & $\begin{array}{l}\text { Acupuncture was } \\
\text { shown to be effective in } \\
\text { improving pain, sleep, } \\
\text { and quality of life in both } \\
\text { groups, but with marked } \\
\text { improvement in the } \\
\text { group that received } \\
\text { acupuncture in the } \\
\text { tender points. }\end{array}$ \\
\hline $\begin{array}{c}\text { [14] (OLIVEIRA; } \\
\text { SOUSA; GODOY, 2014) }\end{array}$ & $\begin{array}{l}\text { The aim of } \\
\text { this study was } \\
\text { to evaluate the } \\
\text { effect of } \\
\text { acupuncture on } \\
\text { electrodermal } \\
\text { activity, quality } \\
\text { of life and pain } \\
\text { reduction in } \\
\text { fibromyalgia } \\
\text { individuals. }\end{array}$ & $\begin{array}{l}\text { These are a series } \\
\text { of cases with } \\
\text { female patients and } \\
\text { aged between } 35 \\
\text { and } 58 \text { years. Three } \\
\text { outcomes were } \\
\text { evaluated: pain } \\
\text { intensity, using the } \\
\text { Visual Analog } \\
\text { Scale (VAS); } \\
\text { quality of life, } \\
\text { investigated by the } \\
\text { Fibromyalgia } \\
\text { Impact } \\
\text { Questionnaire } \\
\text { (QIF); and } \\
\text { electrodermal } \\
\text { activity, verified by } \\
\text { Ryodoraku. }\end{array}$ & $\begin{array}{c}\text { As a result, a } \\
\text { percentage reduction in } \\
\text { pain was observed } \\
\text { between } 34 \% \text { and } 63 \% \text { in } \\
\text { VAS, improvement in } 7 \\
\text { of the } 10 \text { items of the QIF } \\
\text { and an increase in the } \\
\text { mean } \\
\text { electropermeability of } \\
\text { Ryodoraku, from } \\
34.95 \pm 11.12 \text { to } \\
46 \pm 11.66 .\end{array}$ & $\begin{array}{l}\text { The primary outcome } \\
\text { of the study was that } \\
\text { treatment with } \\
\text { acupuncture reduced } \\
\text { pain intensity in all } \\
\text { participants. }\end{array}$ \\
\hline $\begin{array}{l}\text { [15] (DA SILVA } \\
\text { PASSOS; BOAS; } \\
\text { PRATES, 2016) }\end{array}$ & $\begin{array}{l}\text { Thus, this } \\
\text { study aims to } \\
\text { evaluate the }\end{array}$ & $\begin{array}{c}\text { This is a } \\
\text { bibliometric } \\
\text { analysis, where a }\end{array}$ & $\begin{array}{c}\text { Acupuncture has } \\
\text { significantly positive } \\
\text { effects on quality of life, }\end{array}$ & $\begin{array}{c}\text { After reviewing the } \\
\text { selected articles, it was } \\
\text { possible to observe that }\end{array}$ \\
\hline
\end{tabular}




\begin{tabular}{|c|c|c|c|c|}
\hline & $\begin{array}{c}\text { effects of } \\
\text { acupuncture on } \\
\text { fibromyalgia } \\
\text { from a literature } \\
\text { review. }\end{array}$ & $\begin{array}{l}\text { survey of scientific } \\
\text { articles was carried } \\
\text { out in the VHL } \\
\text { database. The } \\
\text { search was } \\
\text { conducted using the } \\
\text { Keywords: } \\
\text { Fibromyalgia, } \\
\text { Acupuncture, and } \\
\text { the search was } \\
\text { carried out in } \\
\text { September } 2016 . \\
\text { We selected } 18 \\
\text { studies since they } \\
\text { addressed the } \\
\text { etiology and } \\
\text { treatment of } \\
\text { fibromyalgia, } \\
\text { including } \\
\text { acupuncture. }\end{array}$ & $\begin{array}{l}\text { sleep, stiffness, anxiety, } \\
\text { depression, and pain of } \\
\text { fibromyalgia patients, } \\
\text { and these effects also } \\
\text { manifest themselves } \\
\text { systemically, through } \\
\text { improved pain from } \\
\text { other points other than } \\
\text { those who have been } \\
\text { treated. }\end{array}$ & $\begin{array}{l}\text { acupuncture was } \\
\text { effective in the treatment } \\
\text { of individuals with } \\
\text { fibromyalgia, obtaining } \\
\text { an improvement in } \\
\text { aspects related to the } \\
\text { quality of life, pain, } \\
\text { sleep, and anxiety. }\end{array}$ \\
\hline [16] (DA SILVA, 2017) & $\begin{array}{l}\text { In this case } \\
\text { study, we had } \\
\text { as main } \\
\text { objectives: to } \\
\text { analyze through } \\
\text { the } \\
\text { questionnaire } \\
\text { the impact of } \\
\text { fibromyalgia on } \\
\text { patients, } \\
\text { observe a } \\
\text { possible } \\
\text { relationship } \\
\text { with serotonin } \\
\text { and the } \\
\text { improvement in } \\
\text { quality of life, } \\
\text { and also } \\
\text { demonstrate } \\
\text { theimportância } \\
\text { and the benefits } \\
\text { of acupuncture } \\
\text { in improving } \\
\text { the quality of } \\
\text { life of patients } \\
\text { with } \\
\text { fibromyalgia } \\
\text { comparing pre } \\
\text { and post } \\
\text { acupuncture. }\end{array}$ & $\begin{array}{l}\text { We studied } 2 \\
\text { patients with } \\
\text { fibromyalgia, who } \\
\text { underwent serum } \\
\text { serotonin dosage, } \\
\text { the application of } \\
\text { the fibromyalgia } \\
\text { impact } \\
\text { questionnaire and } \\
10 \text { acupuncture } \\
\text { sessions. Serotonin } \\
\text { dosages and } \\
\text { questionnaire } \\
\text { applications were } \\
\text { performed } 3 \text { teams, } \\
1 \text { day before the } 10 \\
\text { acupuncture } \\
\text { sessions, } 1 \text { day after } \\
\text { the } 10 \text { acupuncture } \\
\text { sessions and } 30 \\
\text { days after the end of } \\
\text { the } 10 \text { acupuncture } \\
\text { sessions. }\end{array}$ & $\begin{array}{c}\text { A significant } \\
\text { reduction in serum } \\
\text { serotonin and } \\
\text { fibromyalgia impact } \\
\text { questionnaire score were } \\
\text { observed after } \\
\text { acupuncture sessions, } \\
\text { but in the pre-test and } 30 \\
\text { days after both were } \\
\text { increased. The student's } \\
\text { t-test was used for } \\
\text { statistical analysis and } \\
\text { the significance level } \\
\text { adopted was 5\% (p < } \\
0.05 \text { ). }\end{array}$ & $\begin{array}{l}\text { It can be concluded } \\
\text { that, although the } \\
\text { number of patients is } \\
\text { small, acupuncture was } \\
\text { effective in the } \\
\text { short-term treatment of } \\
\text { fibromyalgia, where an } \\
\text { improvement in the } \\
\text { quality of life of the two } \\
\text { fibromyalgia patients } \\
\text { under study was } \\
\text { achieved, and this } \\
\text { improvement may be } \\
\text { related to serum } \\
\text { serotonin reduction. }\end{array}$ \\
\hline
\end{tabular}

\section{CONCLUSION}

It is concluded that acupuncture has physiological bases that prove its effectiveness in the intervention of fibromyalgia symptoms, thus becoming a relevant treatment option for the FM carrier to increase their quality of life, becoming efficient in the decreased pathological manifestations, offering relief from pain, improved sleep and emotional control, as well as an increase in the daily comfort of patients. 


\section{ACKNOWLEDGMENT}

Indexing system and library-NORMATIZA. That during the course, it provided us with the publication of this article.

\section{REFERENCES}

[1]BECK, D. G. DOS S.; OLIVEIRA, G. C. DE. ACUPUNTURA NO TRATAMENTO ÁlGICO DA FIBROMIALGIA: REVISÃO DA LITERATURA. REVISTA SAÚDE INTEGRADA, v. 11, n. 21, p. 2-10, 2018

[2] MARTINS, R. C. C.; SILVEIRA, N. C. EFICÁCIA DA ACUPUNTURA PARA O TRATAMENTO DA FIBROMIALGIA: uma revisão sistemática. Psicologia e Saúde em debate, v. 4, n. 1, p. 85-105, 1 fev. 2018.

[3] ALVES, R. DE C. et al. Sleep Quality and Perception of the Disease in Fibromyagic Patients at the School of Physiotherapy Clinic of Gurupi University. Journal of Advances in Medicine and Medical Research, p. 1-14, 2019.

[4] AZEVEDO, P. M. A ciência da dor: Sobre fibromialgia e outras síndromes dolorosas. [s.l.] Editora UNESP, 2019.

[5] AZEVEDO, D. C. FIBROMIALGIA. 2018.

[6] SIENA, L. R.; MARRONE, L. A influência da alimentação na redução ou no agravamento dos sintomas apresentados em pacientes portadores de fibromialgia. Revista Terra \& Cultura: Cadernos de Ensino e Pesquisa, v. 25, n. 48-49, p. 13-19, 2018.

[7] BONDE. Acupuntura ajuda aliviar dores da fibromialgia. Jornalismo. Disponível em: <https://www.bonde.com.br/>. Acesso em: 10 fev. 2020.

[8] PERES, K. C. O.; MEJIA, D. P. M. Tratamento da lombalgia gestacional com acupuntura: uma revisão de literatura. [s.l: s.n.].

[9] ARAÚJO, W. N. DE et al. Effectiveness of acupuncture and myofascial release in analgesia of women with tensional neck pain: Systematic review. v. 6, n. 12, 30 dez. 2019.

[10] MARANHÃO, A. P. LATO SENSU EM ACUPUNTURA. p. 150, 2017.
[11] SILVA, V. F. D. ABORDAGEM FISIOTERAPÊUTICA NO TRATAMENTO DA FIBROMIALGIA. 2018.

[12] OLIVEIRA, M. DE et al. Experimental Planning Factorial : A brief Review. International Journal of Advanced Engineering Research and Science (IJAERS), v. 6495, n. 6, p. 166-177, 2018.

[13] TAKIGUCHI, R. S., FUKUHARA, V. S., SAUER, J. F., Assumpção, A., \& Marques, A. P. (2008). Efeito da acupuntura na melhora da dor, sono e qualidade de vida em pacientes fibromiálgicos: estudo preliminar. Fisioterapia e Pesquisa, 15(3), 280-284.

[14] DE OLIVEIRA, Raphaela Menezes; DE SOUSA, Hugo Alves; DE GODOY, José Roberto P. Efeito da acupuntura na qualidade de vida e no tratamento da dor em pacientes com fibromialgia-doi: 105102/ucs v12i1. 2820. Universitas: Ciências da Saúde, v. 12, n. 1, p. 37-48, 2014.

[15] DA SILVA PASSOS, Rafael; BOAS, Sara Souza Vilas; PRATES, Rahab Vieira. Efeitos da acupuntura na fibromialgia: Uma revisão bibliométrica. Acta Biomedica Brasiliensia, v. 7, n. 2, p. 15-21, 2016.

[16] DA SILVA, Fernando Rodrigues. A utilização da acupuntura no tratamento da fibromialgia relacionando com a qualidade de vida e a dosagem sérica de serotonina. Fisioterapia Brasil, v. 12, n. 4, p. 298-302, 2017

\begin{tabular}{|l|l|}
$\begin{array}{l}\text { Hello, my name is Eva Coelho da Silva, I am } 25 \text { years } \\
\text { old, I was born on April 29, 1994 in the city of Gurupi, } \\
\text { state of Tocantins, Brazil. I am a graduate student of the } \\
\text { 6th period of Physiotherapy at the University of } \\
\text { Tocantins - Unirg. This will be my first publication of } \\
\text { several that I intend to do. }\end{array}$ \\
$\begin{array}{l}\text { Hello, my name is Dilene Francisca Pereira de Sousa, I } \\
\text { am 32 years old, I was born on December 19, 1987 in } \\
\text { the city of Rubiataba State of Goiás, Brazil. I am a } \\
\text { graduate student of the 5th period of Physiotherapy at } \\
\text { the University of Tocantins - Unirg. My first } \\
\text { publication will be this, an achievement. }\end{array}$ \\
$\begin{array}{l}\text { Hello, my name is Daniela Santos do Nascimento, I am } \\
\text { 21 years old, I was born on August 28, 1998 in the city } \\
\text { of Gurupi, state of Tocantins, Brazil. I am a graduate } \\
\text { student of the 6th period of Physiotherapy at the } \\
\text { University of Tocantins - Unirg. }\end{array}$ \\
\hline
\end{tabular}

